\title{
Arruinamento e regeneraçáo do espaço edificado na metrópole do século XXI: o caso de Lisboa
}

Eduardo Brito-Henriques. Universidade de Lisboa, Lisboa, Portugal.

RESUMO | Ruínas e espaços abandonados são presenças ubíquas nas cidades contemporâneas. Talvez por serem considerados elementos indesejados e anómalos, são um tema pouco tratado nos estudos urbanos. Neste artigo, trabalha-se em vista a uma teoria da ruína urbana moderna. Tomando por referência o caso da área metropolitana de Lisboa (Portugal), sustenta-se que os abandonos e arruinamentos sáo parte integrante da mutabilidade das formas urbanas imposta pelo progresso e que a aceleração do tempo na modernidade, ao radicalizar o obsolescimento dos objetos, intensifica esses processos. Abandonos e arruinamentos tendem a ser mais súbitos e aleatórios, irrompendo no tecido urbano de forma caótica e fractal, tanto em espaços centrais como nas periferias. Demonstra-se, por fim, que as políticas de regeneração urbana estấo a favorecer o reinvestimento nas áreas centrais, embora de forma seletiva, e que se assiste a uma tendência recente de periferização dos arruinamentos.

PALAVRAS-CHAVE | teoria urbana, renovação urbana, áreas metropolitanas.

ABSTRACT | Ruins and derelict spaces are ubiquitous presences in contemporary cities. Probably because they are seen as undesirable and anomalous elements, scarce attention has been paid to them in urban studies. A theory of modern urban ruin is attempted in this paper. Using the Lisboan metropolitan area (Portugal) as case study, it is argued that dereliction and ruinification are part of the mutability of urban forms imposed by progress. The acceleration of time in modernity, by making the obsolescence of objects easier and faster, intensifies those processes. Dereliction and ruinification tend to occur more suddenly and randomly, breaking into the urban space in a chaotic and fractal geography, which reaches both central and peripheral areas. Finally, it is demonstrated that urban regeneration policies are favoring reinvestment in central areas, albeit selectively, and that a trend of ruins shifting to periphery is under way.

KEYWORDS | urban theory, urban renewal, metropolitan areas. 


\section{Introduçáo ${ }^{1}$}

A ruína é uma presença incontornável na cultura visual da modernidade. Entre as gravuras de Piranesi e filmes de ficção científica como Blade Runner e Mad Max há uma linha de continuidade construída sobre a repetição de imagens de destruição e de escombros. Moscovo em cinzas no incêndio de 1812 (Tolstoy em Guerra e Paz), fotos e filmes das cidades bombardeadas na iI Guerra Mundial, a desolação nuclear de Chernobyl, o colapso das Torres Gémeas no 11 de setembro, e as várias formas de paisagem que revestem os fracassos económicos do nosso tempo - das paisagens da desindustrialização às cidades fantasmas das bolhas especulativas - fazem parte de um imenso arquivo iconográfico mental de arruinamentos que transportamos connosco. De Spengler (1926 [1923]) a Virilio (1977) e a Berman (1982), são muitos os autores que denotam que táo estruturais no pensamento moderno quanto os conceitos de progresso e desenvolvimento são as ideias de decadência e calamidade.

A presença da ruína - sobretudo da ruína moderna - tornou-se mais sensível nos últimos anos. $\mathrm{Na}$ arte, o ruin porn emergiu como um novo género fotográfico (vd. Mullins, 2012). Fotografias que exibem com espetacularidade o descalabro de cidades como Detroit fazem sucesso nas galerias de arte, explorando um prazer voyeurista que se compraz/condói com o obsceno dos grandes edifícios públicos e moradias particulares em ruínas. Nas ciências sociais e humanidades assiste-se a um interesse inédito pela ruína moderna e pela sua fenomenologia, a ponto de se falar da emergência de uma "ruinologia" (Martin, 2014a): refazem-se biografias de edifícios em ruínas, escava-se a sua arqueologia, discutem-se os seus sentidos políticos, inquire-se a experiência sensual e a emoção no confronto com a ruína (Abourahme, 2014; Dobraszczyk, 2015; Gandy, 2013; González-Ruibal, 2008; Martin, 2014b; Millington, 2013; Ren, 2014). Nos estudos urbanos, porém, esta reflexão ainda é incomum. Com exceção de raros trabalhos dedicados a refletir sobre as potencialidades urbanísticas de vazios urbanos e espaços abandonados (Solà-Morales, 1995; Berger, 2006), a ruína permanece um assunto tabu que só indiretamente é abordado: de forma implícita ao tratar-se o "encolhimento urbano" (urban shrinkage); ou então através da sua negação na regeneração urbana.

O fato do encolhimento urbano - a perda de população e destruição de emprego, mais visível no Norte Global- se ter tornado num tópico de atualidade náo significa que o arruinamento do espaço edificado, que lhe é inerente, tenha merecido grande atenção. Os estudos focaram-se nos aspetos demográficos e económicos do encolhimento urbano, em averiguar as suas causas, e em discutir as soluçóes de política mais eficazes para responder a esse "problema" (Pallagst, Schwarz, Popper, \& Hollander, 2009; Bontje \& Musterd, 2012; Großmann, Beauregard, Dewar \& Haase, 2012; Hospers, 2014), sem olharem devidamente à dimensão corpórea e palpável que tudo isso tem na destruição do edificado. Também a abundante

1 Este estudo é um produto do Projeto novoid (PTDC/ATP-EuR/1180/2014 - "Ruínas e terrenos vagos nas cidades portuguesas: explorando a vida obscura dos espaços urbanos abandonados e propostas de planeamento alternativo para a cidade perfurada”), financiado pela FCT - Fundaçáo para a Ciência e Tecnologia, Portugal. O autor agradece a Leandro Gabriel a ajuda na preparação da cartografia que ilustra este artigo. 
bibliografia sobre o tema da regeneração urbana obliterou praticamente a reflexão sobre as dinâmicas de arruinamento e respetivas lógicas, reduzindo este assunto a um simples ponto de partida para a discussão - essa sim considerada pertinente - da sua reversāo (Couch, Sykes, \& Börstinghaus, 2011; Segado-Vázquez \& Espinosa-Muńoz, 2015; Tallon, 2010).

A primeira intenção do presente estudo é contrariar esta desatenção, trazendo para o centro do debate o arruinamento do espaço edificado e as suas racionalidades. Não parece possível entender plenamente as transformaçôes da paisagem urbana sem atender a esta componente da sua mutação. O segundo objetivo é refletir sobre a relação entre abandono, arruinamento e regeneração urbana. A tendência dominante na literatura tem sido pôr em contraposição, como se fossem movimentos antagónicos e mutuamente excludentes, abandono e arruinamento, de um lado, e regeneração urbana, do outro; os primeiros são tidos como uma espécie de "anomalia" na evolução das cidades, a última como uma medida terapêutica dirigida à sua solução. A relação, porém, parece ser mais complexa. Apesar dos esforços canalizados para a regeneração urbana nas últimas décadas, designadamente na União Europeia (UE), os resultados são contraditórios. Se algumas cidades inverteram as tendências recessivas e iniciaram processos de recuperaçáo, outras continuaram a perder habitantes e a assistir ao alastramento dos espaços de arruinamento (Kabisch \& Haase, 2011; Rae, 2013; Turok \& Mykhnenko, 2007). Acresce que as dinâmicas de retoma foram, quase sempre, díspares e seletivas, com bairros que rejuvenesceram a par de outros que se afundaram em espirais de abandono e desinvestimento (Buzar et al., 2007; Couch \& Cocks, 2013). Neste artigo, procurar-se-á demonstrar que estes aparentes paradoxos se devem ao facto de arruinamento e regeneração não serem processos contrários e incompatíveis, gerados por forças opostas, mas sim duas faces articuladas do processo de produção do espaço urbano.

Tendo em conta esses objetivos, o artigo estrutura-se em duas partes. Começa por discutir teoricamente a ruína urbana moderna e os processos ruinogénicos. Depois, numa segunda etapa, avança para a relação entre arruinamento e regeneração urbana, examinando o caso de Lisboa. A análise baseia-se em informação de base estatística e documental, com destaque para os censos da habitação, pelo que a parte empírica incide essencialmente no imobiliário residencial. Diga-se que a área metropolitana de Lisboa se afigura um caso de estudo especialmente útil para os objetivos deste artigo por se tratar de um território onde processos de arruinamento e de regeneração urbana têm coexistido lado a lado. Num ambiente geral de euforia imobiliária que levou a uma expansão explosiva das periferias, houve ao mesmo tempo um encolhimento acentuado da cidade-centro. Lisboa foi a segunda cidade capital da uE que mais perdeu população nas duas últimas décadas (Mateus, 2013, p. 250). Quem visita Lisboa vindo da Europa do Norte não fica insensível à degradação do património edificado. Contudo, isso não impediu que, em simultâneo, se dessem movimentos de reinvestimento no ambiente construído, conjugação que contribuiu para a formaçáo de uma paisagem heteróclita onde o novo, o antigo reabilitado e o arruinado aparecem mesclados. 


\section{Em vista a uma teoria da ruína urbana moderna}

O arruinamento urbano é indissociável do abandono do espaço edificado das cidades. Os dois fenómenos andam relacionados. Umas vezes é o primeiro que se antecipa ao segundo: pode acontecer que o arruinamento se inicie com os edifícios ainda ocupados, vindo o abandono a dar-se em consequência do avanço da degradação; outras vezes acontece o contrário: a deterioração do edificado é espoletada e progride depressa após um abandono. Ruínas e ocos urbanos ocorrem por isso normalmente a par, ainda que parte dos espaços ocos das cidades possam ser construçóes novas vazias que não irão necessariamente evoluir para ruínas (imóveis ainda não absorvidos pelo mercado, ou adquiridos para investimento).

As ruínas incluem vários tipos de situaçôes resultantes de processos genéticos variados. A primeira grande distinção corresponde ao que DeSilvey e Edensor (2013, p. 466) chamaram de "ruínas rápidas" e de "ruínas lentas", i.e. ruínas resultantes de destruiçôes súbitas e cataclísmicas (incêndios, bombardeamentos, sismos, tempestades, etc.), e ruínas produzidas por interrupçôes de investimento na manutenção e reparação dos edifícios. Ao contrário das ruínas rápidas, que têm causas autónomas, as últimas têm de ser interpretadas no quadro das dinâmicas urbanas, das quais são subprodutos. É aí que se devem fundar as bases de um modelo teórico-interpretativo do arruinamento urbano.

Uma revisão da teoria urbana a partir desta perspetiva permite identificar várias interpretaçóes possíveis, sistematizáveis em três teses fundamentais: (i) a tese da expansão centrífuga; (ii) a tese da desurbanização; (iii) e a tese da reestruturação pós-fordista. A elas junta-se neste artigo um quarto referencial para a interpretação do arruinamento urbano nas sociedades modernas - a tese do obsolescimento radicalizado - construído a partir das ideias de progresso, movimento, aceleração, e obsolescência/destruição.

A tese da expansão centrífuga foi por muito tempo a fórmula para a explicação dos fenómenos em análise. Os fundamentos encontram-se nos modelos de organização do espaço urbano que a escola sociológica de Chicago desenvolveu no segundo quartel do século passado usando o racional do neodarwinismo social. $\mathrm{O}$ abandono e o arruinamento do ambiente construído explicam-se nesta tese em resultado da racionalidade de famílias e empresas que, nas suas opçóes locativas, migram para "colonizar" novas localizaçóes periféricas, onde podem dispor de mais espaço a custo mais baixo e de construçôes mais modernas, deixando para trás edifícios vetustos que se degradam e são "invadidos" por grupos sociais com menor poder aquisitivo. Esta associação do arruinamento urbano à suburbanização das classes médias e a processos de filtering down dos bairros por elas inicialmente ocupados é uma ideia muito desenvolvida em Hoyt (1939). O abandono e o arruinamento urbanos seriam assim o preço a pagar pela mobilidade social. Uma vez que o movimento se faz do centro para a periferia, os espaços degradados e as ruínas surgiriam, segundo esta tese, nas áreas centrais das cidades, onde se situam os edifícios mais antigos. O modelo das zonas concêntricas de Burguess identificava uma área de derruimento no primeiro anel em torno do CBD - a "zona de transição" ou "zona de deterioração" - e que descrevia 
como "regióes submersas em pobreza, degradação e doença" onde dominavam os "submundos do crime e do vício" (Burguess, 1929, p. 55).

Ecos dessa tese ressoam ainda quando se insiste em interpretar o encolhimento das cidades-centro em resultado da suburbanização e de opçóes residenciais das classes médias. No entanto, o crédito dessa explicação diminuiu bastante depois dos anos 70. A desindustrialização urbana, com o seu atrelado de abandonos e novas ruínas em grande escala, pôs em xeque aquela tese. Tornou-se então necessário procurar num nível macro - no plano estrutural ou dos "grandes processos" - outras explicaçóes para os fenómenos em questão.

É neste contexto que aparece a tese da desurbanização. Ela enquadra-se num novo modelo interpretativo que tomou emprestado da teoria económica o conceito de "ciclo" e o procurou aplicar ao desenvolvimento urbano. Na formulação que lhe deram Van den Berg, Drewett, Klaasen, Rossi e Vijverberg (1982), a teoria do ciclo de vida urbano postula que as cidades passam ao longo do tempo por diferentes fases - urbanização, suburbanização, desurbanização e reurbanização segundo um padrão cíclico de desenvolvimento ativado por mudanças tecnológicas e societais. Um olhar sobre o tempo longo da história das civilizaçóes parece dar respaldo a esta tese, que recupera a velha tradição do pensamento organicista nas ciências sociais, com as suas analogias aos organismos vivos e aos ciclos da natureza. Muitas cidades ao longo da história surgiram, cresceram, tiveram o seu apogeu, e caíram em declínio. Algumas reduziram-se a ruínas, outras conseguiram encontrar novos motivos de prosperidade e recuperar. A tese da desurbanização procura aplicar este raciocínio ao tempo mais breve da urbanização capitalista, vendo o arruinamento urbano como resultado dessa evolução cíclica em que forças generativas e degenerativas se vão sucedendo ao longo do tempo no espaço urbano. Após a suburbanização, que correspondeu ao apogeu da metrópole urbano-industrial, viria a obsolescência dessa forma urbana, traduzida numa perda de vitalidade e na sua degradação física. Contudo, tal não implica necessariamente o fim ou a "morte" da cidade. Para a tese da desurbanização, pode ser táo-só uma extensão do processo de "destruição criativa" de Schumpeter. Passar da desurbanização para uma fase de reurbanização é possível, embora não automático. A inovação é a variável chave para que tal transição possa ocorrer. Para Hall (1998), a inversão do declínio e a entrada numa fase de recuperaçáo urbana dependiam da capacidade das cidades descobrirem novas vocaçóes e respostas de política inovadoras que gerassem novos fatores de atração de população e capital.

A teoria do ciclo de vida urbano tem sido contestada enquanto modelo descritivo da evolução das cidades. A observância do padrão urbanização-desurbanização-reurbanização não está demonstrada empiricamente (Cheshire, 1995; Kabisch \& Haase, 2011). No entanto, foi esta tese que deu o principal embasamento teórico às políticas de regeneração urbana dos últimos trinta anos, tendo-se tornado num instrumento ideológico da reestruturação urbana neoliberal.

Outra interpretação possível para o arruinamento urbano ocorrido em larga escala no último quartel do século xx é a tese da reestruturação pós-fordista, desenvolvida pela escola de geografia económica da Califórnia (e.g. Dear, 2001; Soja, 2000). Inspirados em parte no pensamento lefebvriano, e mais diretamente na escola 
regulacionista francesa (de Michel Aglietta, Alain Lipietz, etc.), os seus autores defendem que as transformaçóes urbanas iniciadas na década de 1970 - entre as quais se inclui o abandono e desmantelamento de uma grande variedade de estruturas associadas à produção e ao consumo de massas, tais como antigas fábricas, blocos de habitação coletiva, docas, linhas e estaçóes de caminho de ferro, grandes salas de cinema (movie theatres) ou armazéns de revenda (department stores) - constituíram expressóes da crise do fordismo, integrando-se num processo amplo de reestruturação em vista à transição para um novo regime de acumulação: a acumulaçấo flexível. Esta leitura integrada das transformaçôes económicas, socioculturais e espaciais é sustentada pela teoria regulacionista que defende que o capitalismo tenta gerir a sua instabilidade intrínseca e reproduzir-se criando mecanismos anticíclicos - modos de regulação - que asseguram equilíbrios temporários. As formas espaciais participam dessa coerência, constituindo uma componente do aparato regulatório do sistema: a cada regime de acumulação correspondem náo só as suas paisagens de produção, mas também modos de habitar, modos de circular e espaços de consumo específicos. Quando a crise se instala, o sistema responde transitando para um novo regime de acumulação, com mudanças que impactam nos territórios e produzem a ruína das estruturas espaciais prevalecentes.

A tese da reestruturação pós-fordista oferece uma justificação plausível para a vaga de ruínas que atingiu as cidades europeias e norte-americanas nas décadas de 1970 e 80, a "idade de ouro do arruinamento industrial" (Edensor, 2005, p. 5). No entanto, não parece que essa tese seja bastante para explicar a formação de ruínas na cidade contemporânea. Resumir as fases ruinogénicas a grandes momentos históricos de rotura no regime de acumulação parece redutor. Crises que não encaixam exatamente nessa tipologia, como o dot-com crash de 2000 nos EuA (Frey, 2005) ou a Grande Recessão global de 2008 (Kitchin, O’Callaghan, \& Gleeson, 2014; Pálsson, 2012), também produziram surtos de arruinamentos, além de que a produção de ruínas parece ser um processo praticamente contínuo e incessante.

As ideias de movimento, inovação e crise/transmutação que aparecem nas teses acima descritas podem ser mobilizadas em conjunto e integradas num racional mais abrangente que forneça outra possibilidade interpretativa para a produção de ruínas urbanas. A tese do obsolescimento radicalizado, que se sistematizará de seguida, tenta fazer isso, tomando como embasamento fundamental o pensamento teórico sobre a modernidade, e somando às ideias anteriores o conceito de aceleraçáo.

A ideia de movimento é essencial na ontologia da ruína. Um movimento é sempre, ao mesmo tempo, um avanço e um recuo: avanço sobre o ponto de chegada; recuo no ponto de partida. A ruína pode ser descrita como o rasto deixado por um movimento, e portanto a forma como um abandono se inscreve fisicamente na paisagem: "ruínas são o sítio do que deixámos para trás" (Beasley-Murray, 2010, p. 212). Por movimento designam-se aqui vários tipos de trajetórias que podem ocorrer em diferentes planos. Pode ser uma deslocação no espaço, como a migração de uma família, a deslocalização de uma empresa, ou a realocação de capitais para outro local; ou pode ser uma deslocação no plano económico - o fim de uma atividade por esgotamento de um recurso ou desaparecimento de uma necessidade, a realocação de capitais para outro sector em busca de lucro mais fácil, uma transferência 
de propriedade -, sendo que a isto se associa também muitas vezes uma deslocação no espaço. Alguns destes movimentos refletem mudanças estruturais, outros podem ser resultantes da agência dos atores individuais e inscreverem-se em lógicas de relação particulares dos sujeitos com os lugares e as formas do ambiente construído.

Assumindo como ponto de partida que a ruína é o vestígio deixado na paisagem por estas várias formas de movimento, percebe-se que todas as sociedades em todos os tempos históricos terão produzido ruínas. As ruínas não são um monopólio dos tempos modernos nem do capitalismo. Não obstante, parece indiscutível que a modernidade agudizou os fenómenos ruinogénicos, ao ponto de haver quem fale de uma "afinidade eletiva entre modernidade e ruína" (Hell \& Schönle, 2010, p. 5); sobre isto lembra Edensor (2005, p. 17) que "o século Xx produziu mais ruínas que alguma vez antes" e que a capacidade de "ruinização" das sociedades contemporâneas parece náo cessar de aumentar.

Uma leitura do mundo estritamente materialista tenderá a ver na economia a explicação para isto. Harvey (1985, 2012 [2010]) fornece instrumentos para se interpretar a ruína do ambiente construído como expressão das crises capitalistas e das contradiçôes autodestrutivas do sistema. Na sua ânsia de se multiplicar infinitamente, o capital está sujeito a um dinamismo expansionista que o obriga a uma permanente migração em busca de melhores condiçóes de acumulação, com recuo nas regiôes e nos sectores onde aquela começa a chegar ao seu limite. O movimento a que acima se aludiu não seria, deste ponto de vista, senão a circulação do capital.

Outros autores, sem negarem a crucialidade das lógicas económicas, sustentam que o motivo que move as sociedades modernas não é simplesmente o acúmulo de capital. É possível que a ideia de progresso, e a de desenvolvimento que lhe vem atrelada, não seja um produto ideológico do capitalismo, mas antes a própria ideia fundadora da modernidade, que o capitalismo incorporou e que explora em favor da acumulação (cf. Berman, 1982; Bury, 1920; Horkheimer \& Adorno, 2002 [1944]). Deste prisma, a agudização do arruinamento seria uma inerência da modernidade e dessa centralidade da ideia de progresso. $\mathrm{O}$ desejo de progresso impôs às sociedades modernas um permanente "movimento em frente", um imperativo de avançarem sempre e mais. Mesmo tendências que podem simular um "andar para trás", como a estética retro, a moda dos produtos vintage, ou o consumo do património e da memória no turismo e no retorno aos bairros históricos das cidades, surgem como "novidades" e é nessa qualidade que reside parte importante do seu potencial de sedução. Porém, o progresso - como diziam Horkheimer e Adorno (2002 [1944], p. xvi) - contém em si "o gérmen da regressão": avançar implica sempre que se descartem ou desmantelem estruturas do passado, o que faz da modernidade um "turbilhão de perpétua desintegração e renovação" (Berman, 1982, p. 15). Criar algo novo implica quase sempre o abandono de outro algo que esse inovar tornou arcaico; inovação e obsolescência andam portanto de mãos dadas, formam duas faces da mesma moeda. O sentimento de descartabilidade e obsolescência que Baudrillard (1970) identifica na relação com os objetos de consumo em resultado desta premência de inovar, poderemos nós entender que se estende também às formas imóveis da cultura material. O arruinamento intensificado do espaço edificado será a expressão no corpo das cidades desta dialética do progresso. 
A modernidade é sinónimo não só de novo, mas também de velocidade. Virilio (1977, 1993) sustenta que o domínio da velocidade se tornou a procedência vital do poder na modernidade - das várias formas de poder, do poderio económico ao poderio político e militar - e que, como tal, a aceleração se converteu na sua principal obsessão e realização. A aceleração, obtida pelo esforço inventivo de motores cada vez mais potentes, capazes de velocidades crescentes - da máquina a vapor, ao foguete espacial, ao motor informático que permite a comunicação instantânea à escala global e o processamento de informação em microssegundos -, tornou a sociedade moderna mais mutável e móvel do que qualquer outra antes na história. A rotação mais rápida e a hipermobilidade do capital inscrevem-se neste caminho. O resultado foi o que Rosa (2013 [2005], p. 77) chama de "contração do presente", conceito que remete não apenas para o aceleramento dos ritmos de vida, mas também para a transfiguração mais fácil e rápida do atual e moderno em pretérito e ultrapassado. É compreensível que este obsolescimento radicalizado se exprima na paisagem sob a forma de abandonos mais frequentes, súbitos e rápidos e na descartabilidade das edificaçóes e do ambiente construído em geral. Em regiôes marginalizadas, os processos ruinogénicos gerados pela dialética do progresso não são facilmente compensados por reinvestimentos e reenchimentos, e por isso proliferam nelas os espaços de ausência e devastação, com o acumular de sucessivas camadas de ruínas na paisagem. Em regióes economicamente dinâmicas, privilegiadas pelos novos circuitos globais da acumulação, esses rastos de movimentos são rapidamente apagados e os seus locais reocupados. Aí ocos urbanos e ruínas nunca perduram muito tempo na paisagem; tornam-se antes a base da "cidade mutante" de que falava Carlos (2007, p. 46), onde "construçóes, demoliçóes e reformas sáo tantas e táo freqüentes, que praticamente, se pode dizer que são parte integrante da paisagem urbana”.

\section{O caso de Lisboa}

\section{Progresso e abandono: expansão urbana e produção de ocos e ruínas}

A área metropolitana de Lisboa, que estatisticamente corresponde à Região (NUTE II) de Lisboa (3.015 km², englobando dezoito municípios), tinha à data do último censo 2,8 milhóes de habitantes, concentrados num território de povoamento antigo. Admite-se que a fundação do primeiro núcleo proto-urbano tenha sido fenícia, talvez do século vir a.c., e o estatuto urbano remonta ao século I d.c. Desde o século XIII que Lisboa é o centro do espaço económico português. Nos séculos XVI e XVIII, como sede dos descobrimentos marítimos e depois como capital de império, esteve entre as maiores e mais prósperas cidades da Europa. Heranças dessas épocas persistem na morfologia urbana, na toponímia, em monumentos que resistiram aos sucessivos arrasamentos que a cidade sofreu ao longo do tempo (batalhas, incêndios, terramotos), ou ocultas no subsolo, sob as fundações das construçóes atuais, e no esqueleto de edifícios que foram sendo sucessivamente modificados e refeitos ao longo da história.

Ao mesmo tempo, esta é uma regiáo metropolitana moderna. Foi a partir de finais do século XIX que se deu a grande expansão urbana. Entre 1900 e 1950, a população residente na Região de Lisboa passou de meio milhão para 1,3 milhôes de habitantes. Duplicaria novamente até ao final do século. Mas se até meados do século xx esse crescimento foi acomodado maioritariamente na cidade, através da 
densificação e verticalização, da expansão em novos bairros planeados (Avenidas Novas, Campolide, Alvalade, Bairro das Colónias, Restelo, Encarnação, etc.), e com a formação de uma primeira coroa de núcleos suburbanos às portas de Lisboa, dos anos 60 em diante deu-se uma suburbanização "explosiva" da periferia sob diversas tipologias morfológicas e construtivas: bairros de habitação coletiva e bairros de moradias unifamiliares, de promoção pública e de promoção privada (a maioria), bairros planeados e bairros de génese ilegal. A urbanização alastrou para espaços cada vez mais distantes, sob formas também cada vez mais deslaçadas e desconexas, até culminar na coroa periurbana - um território de edificado difuso, onde o natural, o rural e o urbano se interpenetram numa paisagem mesclada e fragmentária (figura 1). Neste decurso, milhares de hectares de solo rural foram convertidos em solo urbano. Só entre 1981 e 2011, aumentou em 140 mil o número de edifícios de habitação e os alojamentos cresceram 74\% (de 853 mil para 1.487 milhares), embora o número de famílias tenha aumentado $42 \%$ e a população residente $14 \%$ (tabelas 1 e 2). Com isso houve uma enorme multiplicação dos ocos urbanos, entre produção excedentária de construções novas e velhos edifícios que entretanto foram abandonados: o número de alojamentos sem ocupantes cresceu, nestes 30 anos, em $136 \%$, passando de cerca de 78 mil para quase 185 mil no conjunto da área metropolitana. Simultaneamente, deu-se uma intensa renovação urbana: a aparência rural da periferia de Lisboa esvaneceu-se e na cidade-centro - sobretudo nos bairros burgueses do século XIX (em redor do Marquês de Pombal, Avenidas Novas, Campo de Ourique, etc.) - construçóes fin-de-siècle e art nouveau deram lugar a torres de escritórios e modernos edifícios residenciais. Assim, em 2011 só 5\% dos edifícios residenciais da Região de Lisboa eram construçóes anteriores a 1919, enquanto 77\% dos edifícios tinham sido construídos após 1960 e 45\% depois de 1980.

Essa renovação foi acompanhada por outras manifestaçôes de modernização. Num lapso de tempo breve de vinte a trinta anos, houve uma transmutação profunda da paisagem. Os espaços de circulação foram melhorados por investimentos milionários em rodovias rápidas e na expansão das redes de metropolitano e ferrovia. A paisagem produtiva alterou-se com o advento de indústrias de alta tecnologia e modernos parques de escritórios para serviços financeiros e de consultoria, nomeadamente em localizaçôes periféricas servidas pelas novas acessibilidades (André \& Vale, 2012). A paisagem do consumo mudou também com a difusão de lojas modernas e sofisticadas de cadeias internacionais e o aparecimento de novos espaços de distribuição de grande dimensão na auréola da cidade-centro e nos municípios periféricos (Barata Salgueiro, 2001) - hipermercados, shoppings, retail parks, outlet stores, etc.

Todas essas transformaçóes têm que ver com o ciclo de prosperidade económica que o país viveu após a adesão à ue (Gaspar, Brito Henriques \& Vale, 1998). De 1986 até 2011, Portugal recebeu mais de 81 mil milhóes de euros de fundos comunitários (preços constantes de 2011), gerando um investimento total superior a 156 mil milhôes de euros (Mateus, 2013, p. 482). O PIB português quase duplicou entre 1985 e 2007, passando de 92,1 mil milhóes de euros para 181,1 mil milhóes (preços constantes de 2011), com as maiores expansóes de 1986 a 1992, e novamente de 1996 a 2000, períodos em que as taxas de crescimento anuais do PIB foram superiores a $3 \%$ e chegaram a ultrapassar em alguns anos os $7 \%$. 


\section{FIGURA I | A área metropolitana de Lisboa}

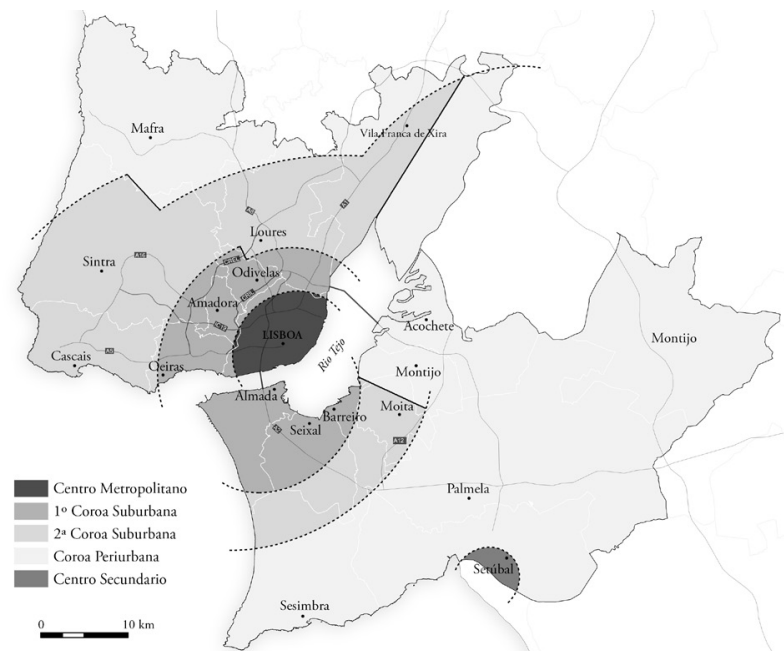

FONTE ELABORAÇÃO PRÓPRIA

A massiva produção de espaço urbano nestes anos pode ser interpretada como uma migração do capital para o circuito secundário da acumulação (Harvey, 1985). Contudo, esses foram também anos de intensa destruição do edificado. Inovação e obsolescência, crescimento e degeneração caminharam a par, como sugere a dialética do progresso. Ao mesmo tempo que as paisagens da produção e do consumo se modernizaram, a desindustrialização deixou um rasto de edifícios fabris arruinados nas frentes ribeirinhas e o comércio tradicional das áreas centrais entrou em declínio, decadência que entretanto se dilatou a uma primeira geração de shoppings surgidos nas décadas de 70 e 80 (Ferreira, 2015), ou seja estruturas mais associadas às paisagens da acumulação flexível que do fordismo.

TABEla I | Evolução demográfica na área metropolitana de Lisboa, 1981-2011

\begin{tabular}{|c|c|c|c|c|c|c|}
\hline \multirow{2}{*}{$\begin{array}{c}\text { ÁREA METROPOLITANA DE } \\
\text { LISBOA }\end{array}$} & \multicolumn{3}{|c|}{ POPULAÇÃO } & \multicolumn{3}{|c|}{ FAMÍLIAS } \\
\hline & I98 I & $20 I I$ & $\Delta \%$ & I98I & $201 \mathrm{I}$ & $\Delta \%$ \\
\hline Centro metropolitano (Lisboa) & 807.937 & 547.733 & $-32,2$ & 285.960 & 243.892 & $-14,7$ \\
\hline 1 a Coroa suburbana & 638.117 & 902.868 & 41,5 & 201.362 & 370.097 & 83,8 \\
\hline 2a Coroa suburbana & 785.826 & 992.283 & 26,3 & 242.904 & 386.250 & 59,0 \\
\hline Coroa periurbana & 152.030 & 257.807 & 69,6 & 49.618 & 99.208 & 99,9 \\
\hline Centro secundário (Setúbal) & 98.366 & 121.185 & 23,2 & 30.926 & 48.328 & 56,3 \\
\hline Área Metropolitana de Lisboa & 2.482 .276 & 2.821 .876 & 13,7 & 810.770 & 1.147 .775 & 41,6 \\
\hline
\end{tabular}

FONTE INE, CENSOS I98 I E 20 II 
TABELA 2 | Evolução do edificado na área metropolitana de Lisboa, 1981-2011

\begin{tabular}{|l|c|c|c|c|c|c|}
\hline \multirow{2}{*}{$\begin{array}{c}\text { ÁREA METROPOLITANA DE } \\
\text { LISBOA }\end{array}$} & \multicolumn{2}{|c|}{ EDIFÍCIOS RESIDENCIAIS } & \multicolumn{3}{c|}{ ALOJAMENTOS CLÁsSICOS } \\
\cline { 2 - 7 } & $\mathbf{I 9 8} \mathbf{I}$ & $\mathbf{2 0 I} \mathbf{I}$ & $\mathbf{\Delta} \%$ & $\mathbf{I 9 8} \mathbf{I}$ & $\mathbf{2 0 I} \mathbf{I}$ & $\boldsymbol{\Delta} \%$ \\
\hline Centro metropolitano (Lisboa) & 57.599 & 52.496 & $-8,9$ & 259.191 & 322.932 & 24,6 \\
\hline 1 ${ }^{\text {a Coroa suburbana }}$ & 64.792 & 123.578 & 90,7 & 220.512 & 466.542 & 111,6 \\
\hline 2a Coroa suburbana & 119.420 & 161.004 & 34,8 & 274.991 & 490.886 & 78,5 \\
\hline Coroa periurbana & 51.071 & 87.637 & 71,6 & 63.679 & 143.739 & 125,7 \\
\hline Centro secundário (Setúbal) & 15.932 & 24.242 & 52,2 & 34.462 & 62.854 & 82,4 \\
\hline Área Metropolitana (Total) & 308.814 & 448.957 & 45,4 & 852.835 & 1.486 .953 & 74,4 \\
\hline
\end{tabular}

FONTE INE, CENSOS I98 I E 20 II

Um corolário do surto modernizante acima descrito foi o encolhimento do centro metropolitano. De 1981 para 2011, Lisboa-cidade perdeu praticamente um terço da população, desapareceram $9 \%$ dos edifícios de habitação em resultado de demoliçôes e conversóes para outros usos, e o número de alojamentos sem ocupante (exclui residências secundárias) aumentou 208\%, subindo para mais de 50 mil. Em 2011, 790 prédios de habitação aguardavam demolição no centro metropolitano e $3 \%$ dos edifícios (cerca de mil e quinhentos) foram classificados no censo desse ano como "muito degradados". ${ }^{2}$ Além destas situações de deterioração extrema, quase 12 mil imóveis necessitavam de intervençôes urgentes segundo avaliaçóes do município de Lisboa, estimando-se que fossem necessários 8.000 milhóes de euros para a sua reabilitação (Simóes, 2011).

Muitas dessas transmutações urbanas são explicáveis em resultado de mudanças estruturais, mas nem tudo encaixa na tese da reestruturação pós-fordista. A tese da desurbanização também falha porquanto a evolução demográfica da Região de Lisboa escapou ao padrão definido no modelo de Van den Berg et al. (1982): Lisboa-cidade perdera população nos anos 60, ganhou população nos anos 70, e entrou novamente em perda depois de 1980, mas a área metropolitana continuou a crescer ininterruptamente em todo o período. Por outro lado, só aparentemente a tese da expansão centrífuga ajuda a compreender o que se passou. É verdade que o encolhimento do centro metropolitano se relacionou com a mobilidade social de estratos das classes média e média-baixa que puderam aceder a casa própria na periferia (população que vivia em habitaçôes precárias, em fogos sobrelotados, ou em casas antigas sem o conforto desejado), mas, em simultâneo, logo desde os anos 80, houve movimentos de apropriação da centralidade por parte de grupos privilegiados

2 Em Portugal, os censos da habitação incluem informação sobre o estado de conservação dos edifícios desde 2001. A caracterização é feita em função da magnitude das reparaçôes de que necessitam, considerando as necessidades ao nível da estrutura, da cobertura e das paredes e caixilharias. Os imóveis são classificados em três categorias: edifícios "sem necessidade de reparação", "com necessidade de reparação" e "muito degradados". Classificam-se nesta última categoria os imóveis que apresentam, cumulativamente, carências de reparaçôes extremas ao nível da estrutura, da cobertura e das paredes e caixilharias. Na prática, traduzem situaçôes de imóveis em risco e sem condiçóes de habitabilidade em razão do seu avançado estado de deterioraçấo. 
com a construção de novos produtos imobiliários de luxo na cidade-centro (Barata Salgueiro, 1994). Além disso, essa tese é incapaz de explicar a geografia dos ocos urbanos e dos espaços de arruinamento.

Um zooming aos alojamentos vagos a partir dos dados do último censo mostra que só parte dos fogos vazios eram espaços abandonados no centro metropolitano, havendo antes uma distribuição difusa e generalizada (figura 2). As concentraçóes máximas ocorriam nos bairros históricos de Lisboa (no núcleo que vai de Santos-Lapa até à Graça, subindo da Baixa ao Marquês de Pombal), declinando depois gradualmente para as franjas do centro metropolitano e primeira coroa suburbana. Contudo, recrudesciam de novo na periferia, registando densidades elevadas na segunda coroa suburbana e na coroa periurbana. Parte destes ocos urbanos eram prédios antigos abandonados, mas outra parte era habitação nova excedentária não absorvida pelo mercado e alojamentos adquiridos para investimento, sendo que situaçôes destes dois tipos ocorriam tanto no centro metropolitano como nas periferias.

FIGURA 2 | Alojamentos vagos na área metropolitana de Lisboa, 2011

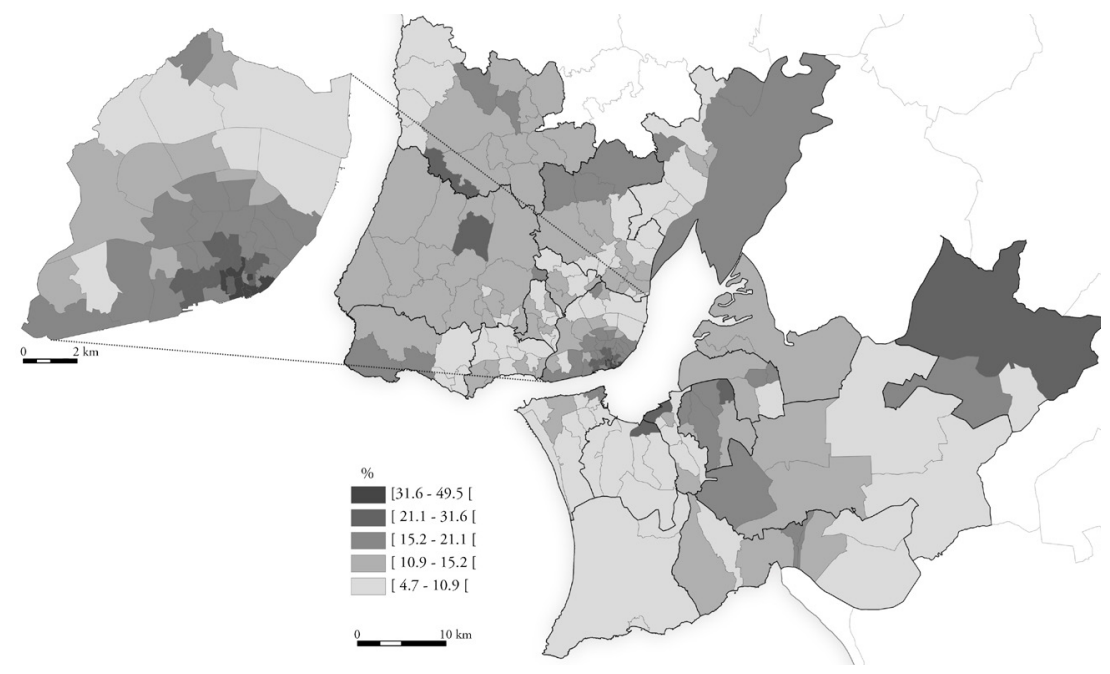

FONTE INE, CENSO 20 I I

Também é equívoco supor que os espaços de arruinamento se confinam ao centro metropolitano (figuras 3 e 4). Os dados do censo da habitação de 2011 revelam que só $23 \%$ dos edifícios "muito degradados" da área metropolitana estavam na cidade de Lisboa, apesar de aqui se situarem 46\% dos imóveis construídos antes de 1919 e $80 \%$ dos imóveis construídos até 1945 . Várias freguesias ${ }^{3}$ da periferia possuíam edifícios "muito degradados" em proporçóes comparáveis às do centro metropolitano; por outro lado, embora as concentraçóes mais elevadas de imóveis nestas condiçóes

$3 \longdiv { \text { Freguesia é, em Portugal, a menor divisão administrativa, correspondendo a uma autarquia local } }$ de nível inframunicipal (os municípios têm a designação de concelhos). A sua matriz original são as jurisdiçóes paroquiais. Nas cidades podem ser assemelhadas a bairros ou partes de bairros. 
se registassem no núcleo histórico de Lisboa, o cenário não era aí homogéneo: havia sectores onde essa presença atingia proporçóes máximas - a Baixa Pombalina, especialmente a parte mais a norte, a Mouraria e Graça, e a parte baixa de Alfama - mas também outras áreas onde a sua frequência era pouco relevante - por exemplo, na Lapa, Chiado, São Mamede (eixo Príncipe Real-Rato-Jardim das Amoreiras) ou em redor da Avenida da Liberdade.

FIGURA 3 | Edifícios muito degradados na área metropolitana de Lisboa, 2011

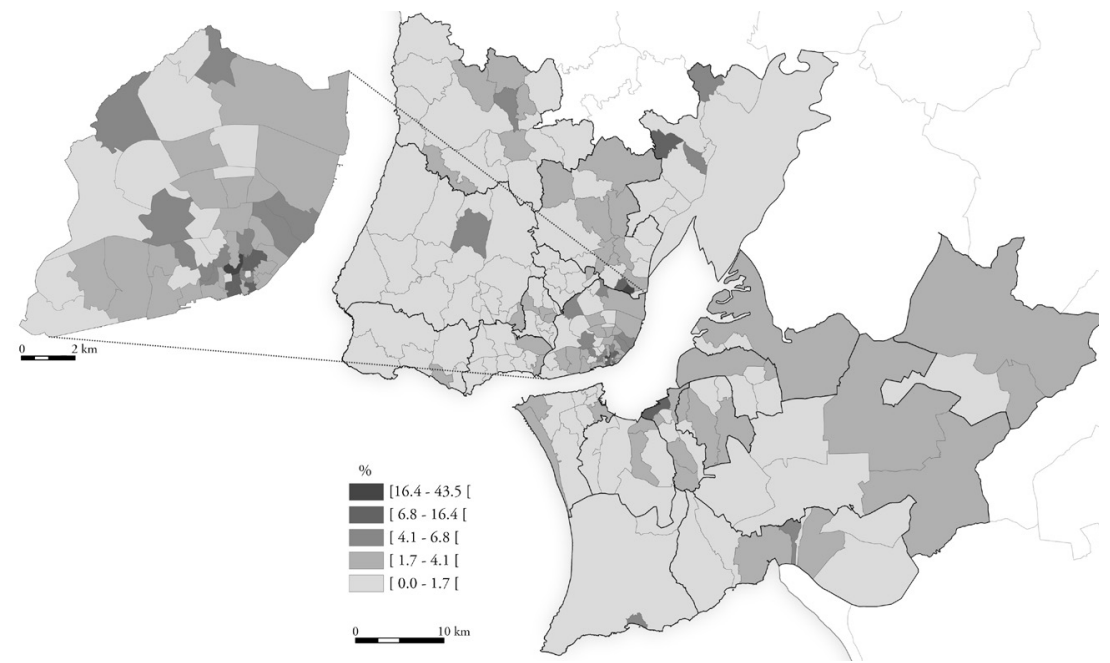

FONTE INE, CENSO 20 I I

FIGURA 4 | Edifícios para demolir na área metropolitana de Lisboa, 2011

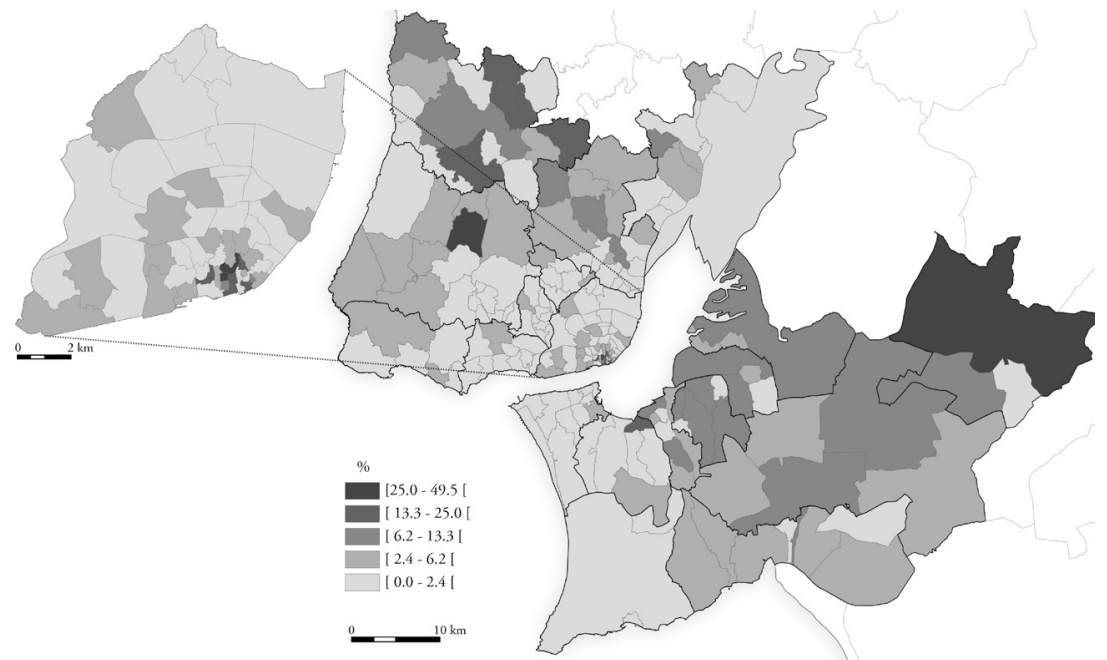

FONTE INE, CENSO 20 I I 
A complexidade da situação era ainda mais evidente se analisássemos a distribuição dos prédios residenciais para demolir. Nesta matéria, não se pode dizer sequer que houvesse uma primazia clara do centro metropolitano: a dispersão na periferia dos edifícios para demolir era patente, com uma notória prevalência dessas situaçóes na segunda coroa suburbana e na coroa periurbana. Por outro lado, as disparidades no núcleo histórico de Lisboa eram ainda mais visíveis do que sucedia com o estado de conservação dos imóveis. Tais contrastes revelavam a coexistência no próprio centro histórico, a pouca distância, de dinâmicas bastante divergentes de reinvestimento/ reocupação e de marginalização/abandono do espaço edificado.

\section{Reinvestimentos na cidade-centro e periferizaçáo do arruinamento}

A expressão do progresso material na paisagem, nas formas da expansão urbana periférica e da renovação urbana acima descritas, produziu sentimentos contraditórios. Logo na década de 80, uma nova geração de arquitetos-jornalistas ganhou voz nos media para denunciar os "atropelos" e as "atrocidades" infligidos à cidade com o abandono do centro e as demoliçôes do edificado, o avanço massivo da terciarização e da construçáo em altura, e ao mesmo tempo censurar a falta de qualidade urbanística e a anomia dos subúrbios em crescimento (Reis, 2007). A perda de populaçáo no centro metropolitano tornou-se motivo de apreensão para as autoridades municipais, em parte pelas consequências para as finanças da cidade. A reabilitação urbana despontou então como tema na agenda política. Em 1986 foram criados os Gabinetes Técnicos Locais de Alfama e da Mouraria, e em 1988 o do Bairro Alto e Bica, com a missão de garantir a salvaguarda destes bairros históricos e apoiar os privados na reabilitação do edificado. Os modelos de regeneração urbana aplicados internacionalmente na reconversão de docas e na realização de megaeventos chegaram nos anos 90, marcando a entrada em Lisboa do "urbanismo neoliberal" (Peck, Theodor \& Brenner, 2009). O ponto alto foi a realização da Expo'98, operaçáo que envolveu uma área de 340 hectares ao longo de mais de $5 \mathrm{~km}$ da frente do Tejo com o intuito de transformar um antigo espaço portuário e industrial em decadência num novo bairro residencial, de comércio e de serviços - o Parque das Naçóes - projetado para mais de 20.000 habitantes e destinado aos estratos altos e médio-altos da população.

Nos anos que se sucederam, outras medidas foram tomadas para estimular a regeneração do edificado e a reocupação da cidade consolidada. Destaca-se a promulgação do regime jurídico especial para a reabilitação urbana em 2004 (Decreto-Lei $\mathrm{n}^{\circ} 104 / 2004$, de 7 de maio), destinado a fomentar e agilizar este tipo de operaçóes; para além de ter instituído a figura das sociedades de reabilitação urbana (SRU) - empresas de capitais públicos com o objeto social de promover e conduzir a reabilitação urbana, sob diversas formas de parceria com empresas de capitais privados -, o diploma simplificou os procedimentos legais a observar nas operaçóes urbanísticas por elas desenvolvidas e fomentou a constituição de fundos de investimento imobiliário com esse fim. Em 2007 criou-se um regime fiscal extraordinário para a reabilitação, destinado a vigorar entre 2008 e 2012 (Lei no 67-A/2007, de 31 de dezembro), com benefícios para os proprietários de imóveis reabilitados (isençáa do imposto municipal sobre imóveis até 5 anos), e benefícios ainda mais 
generosos para os fundos de investimento imobiliário cujos ativos fossem maioritariamente afetos a obras de reabilitação (isenção de imposto sobre rendimento dos fundos, assim como tributação excecional reduzida a 10\% para os rendimentos de unidades de participação nesses fundos). Tais disposiçóes favoreceram a penetração do capital financeiro no segmento da reabilitação, aumentando a escala das intervenções e atraindo um novo tipo de promotores sofisticados e vinculados aos circuitos globais. A essas medidas veio somar-se um programa de investimentos em regeneração urbana comparticipado por fundos comunitários. Este instrumento Parcerias para a Regeneração Urbana (PRU) - permitiu cofinanciar a partir de 2008 mais de duas centenas de operaçóes no conjunto da Região de Lisboa, integradas em 28 planos de ação onde se aplicaram 66,6 milhóes de euros de FEDER até finais de 2013. A maioria destas operaçôes (64\%) incidiu nos núcleos históricos e nas frentes ribeirinhas e consistiu em obras de qualificação e embelezamento do espaço público, complementadas por valorizações do património com vista à instalação de equipamentos. A intenção era que investindo nas amenidades urbanas se atraísse investimento privado para o imobiliário.

A eficácia dessas medidas foi limitada se atendermos aos objetivos que técnica e politicamente eram invocados: não contiveram a dispersão do edificado nas periferias, e náo inverteram a perda de população do centro metropolitano. Contudo, criaram condiçóes atrativas de reinvestimento em espaços devolutos e arruinados, que beneficiaram sobretudo as localizaçóes centrais. É um facto que o investimento continuou a privilegiar desproporcionadamente as construçóes novas em detrimento de obras sobre edifícios já existentes: entre 1995 e 2013, reabilitaram-se 3,7 milhôes de $\mathrm{m}^{2}$ na Região de Lisboa (entre ampliaçôes, alterações e reconstruções de imóveis), enquanto foram produzidos 59,5 milhões de $\mathrm{m}^{2}$ em edifícios novos. Porém, a reabilitação urbana ganhou relevância com a viragem do século. Entre 2002 e 2007, as obras em edifícios existentes aumentaram a um ritmo superior ao das construçôes novas (gráfico 1). A partir de 2008, com a crise financeira global e depois a crise da dívida soberana na zona euro, todo o sector imobiliário se retraiu, mas a reabilitação urbana não caiu táo a pique como as construçóes novas - em parte graças ao regime extraordinário de que beneficiava -, de modo que a quota das operações de remodelação, ampliação e reconstrução no total das obras concluídas passou de 6\% em 2002 para quase 25\% em 2013.

Ao longo da primeira década do século XXI - um período em que a economia portuguesa estagnou - o estado de conservação do edificado melhorou em termos gerais. Os edifícios "muito degradados" reduziram-se em $31 \%$ e os imóveis "sem necessidade de reparação" aumentaram 36\% na área metropolitana de Lisboa. Essas melhorias explicam-se pela continuação da renovação do edificado, mas também em resultado da reabilitação urbana, que progrediu de modo especial na cidade-centro. Entre 2001 e 2011, o número de imóveis anteriores a 1919 com uso habitacional aumentou em cerca de meio milhar no centro metropolitano (imóveis situados nos bairros históricos), e circunstância similar ocorreu com 1.400 imóveis de várias linguagens modernistas construídos de 1946 a 1960 (imóveis dispersos, mas com maior concentração nos bairros burgueses dos séculos XIX e Xx - Campo de Ourique, Marquês do Pombal-Parque Eduardo viI, Avenidas Novas, Areeiro, 
etc.), correspondendo a edifícios antes devolutos ou com uso não residencial que se reconverteram para habitação. A maior parte desta oferta destinou-se aos segmentos médios-altos e altos da procura, consistindo em prédios interiormente modernizados para propiciarem condiçóes de conforto elevadas. Em resultado, reduziu-se em $27 \%$ o número de imóveis residenciais anteriores a 1919 "muito degradados" e aumentou em $114 \%$ o de prédios desta época "sem necessidade de recuperação".

GRÁFICO I | Evolução das construçôes novas e reabilitação de imóveis na área metropolitana de Lisboa, 1995-2013

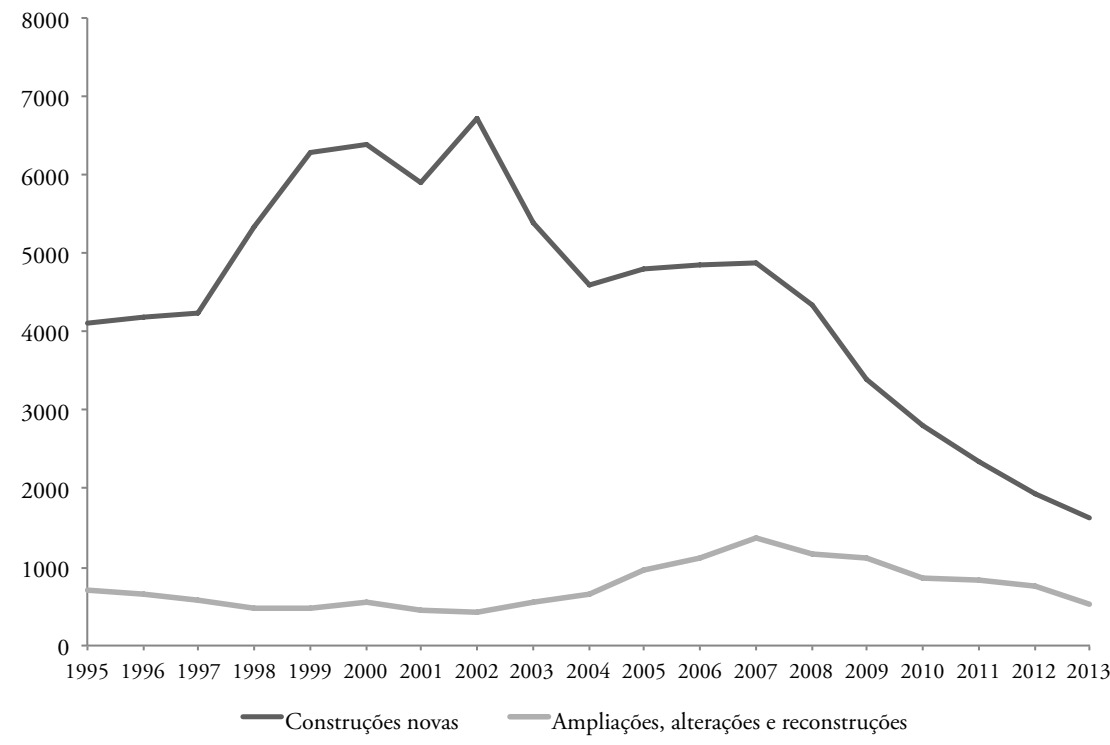

FONTE INE, ESTATÍSTICAS DA CONSTRUÇĀO (VÁRIOS ANOS)

Essa regeneraçáo do edificado náo impediu que os arruinamentos prosseguissem. Por vezes nos mesmos bairros, e até nas mesmas ruas, em que certos prédios foram reabilitados, outros foram abandonados e entraram em deterioração. Num cenário geral de diminuição dos imóveis "muito degradados", que incluiu o centro metropolitano, especialmente as localizaçóes de prestígio no seu núcleo histórico, registaram-se pontualmente agravamentos dessas situaçóes, como no Bairro Alto, Santa Justa-Socorro, parte de Alfama e na Graça (figura 5). É de notar que o Bairro Alto fora das primeiras áreas do centro histórico de Lisboa a conhecer processos de gentrificação nos anos 90 (Mendes, 2008). Tal situaçáo corrobora a ideia de uma mutabilidade mais rápida das procuras e de uma hipermobilidade do capital que tem que ver com a turbulência da aceleração e se traduz numa instabilidade acrescida na relação com o ambiente construído. Alguns focos de degradação surgiram entretanto nas expansóes modernas da cidade de Lisboa. Mas foi sobretudo para as periferias da área metropolitana que o arruinamento migrou, facto que resulta também visível quando se atenta no aumento dos imóveis para demolição (figura 6). 
Importante ressaltar ainda é que a esta periferização do arruinamento se ligou um avanço mais rápido da deterioraçáo sobre imóveis modernos, nomeadamente blocos de apartamentos já da segunda metade do século xx, o que vem em favor da ideia de um obsolescimento cada vez mais rápido do edificado.

FIGURA 5 Crescimento dos edifícios muito degradados na área metropolitana de Lisboa, 2001-2011

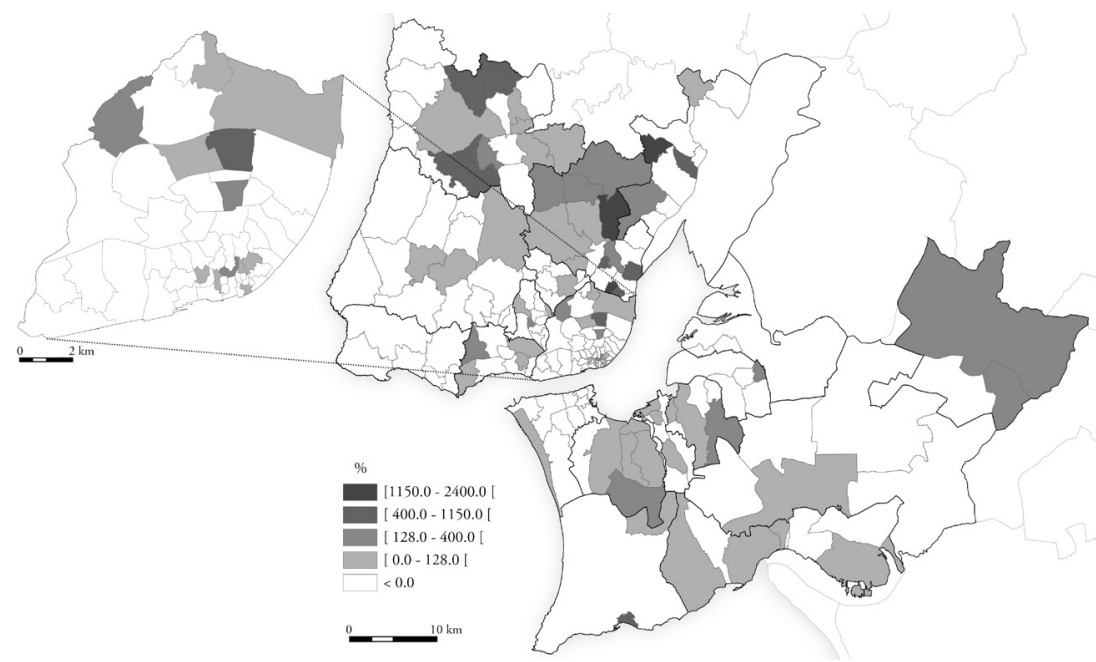

FONTE INE, CENSOS 2OOI E 2OII

FIGURA 6 | Crescimento dos edifícios para demolir na área metropolitana de Lisboa, 2001-2011

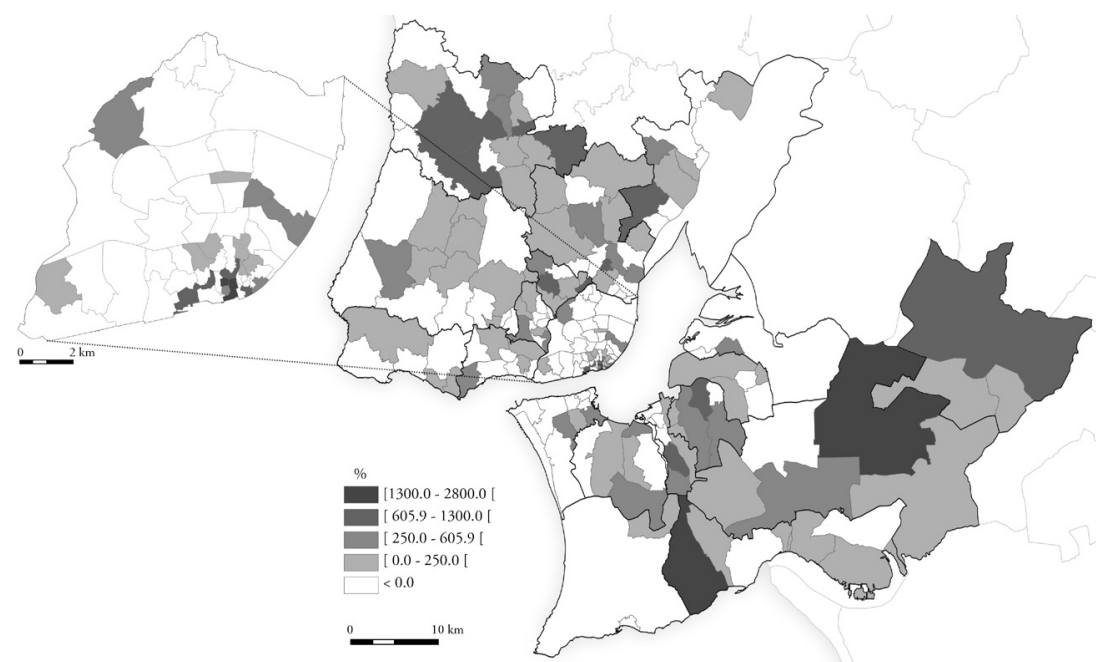

FONTE INE, CENSOS 2OOI E 20 I I 


\section{Conclusão e comentários finais}

O caso de Lisboa fornece evidências que parecem confirmar a utilidade da tese do obsolescimento radicalizado na interpretaçáo dos fenómenos ruinogénicos na metrópole contemporânea. A expressão da dialética do progresso na materialidade do caso descrito ficou bem patente. $\mathrm{O}$ contexto de acentuado progresso material vivido nos últimos decénios não inibiu - muito pelo contrário - que, em simultâneo com uma expansão em larga escala do edificado e a modernização do ambiente construído, parte do tecido urbano fosse abandonado e senescesse, numa conjugaçáo de movimentos de enchimento e abandono, e de renovação e destruição do ambiente construído. Por outro lado, frentes novas de arruinamento progridem hoje em áreas de desenvolvimento recente, formas construídas que ainda há escassas décadas eram novidades tornam-se obsoletas (como os shoppings moribundos dos anos 70 e 80, ou os blocos de habitação plurifamiliar modernos que se arruínam nas periferias), e espaços decadentes transmutam-se em espaços regenerados e vice versa, numa convulsão de mudanças que parece confirmar os efeitos da aceleração do tempo na volubilidade das formas urbanas e na tendência para que o atual depressa se torne ultrapassado.

A análise desenvolvida deixou também patente a falta de correspondência entre as imagens teóricas que se fazem dos espaços de arruinamento - intuitivamente associados às áreas urbanas centrais - e a realidade, demonstrando a ineficácia das explicaçôes mais comuns na descrição de como os ocos urbanos e as ruínas se dispartem no espaço metropolitano. A realidade nega o simplismo de um modelo centro-periferia em que a um centro obsoleto, esvaziado e degradado se opóe uma periferia nova, inchada e pujante. Frentes de arruinamento avançam nas periferias e nas auréolas periurbanas onde os ocos urbanos se acumulam, ao mesmo tempo que continuam corroendo partes do centro metropolitano, onde dinâmicas divergentes de regeneração se encontram, contudo, igualmente ativas. A consequência no tecido urbano deste obsolescimento radicalizado característico da modernidade contemporânea é uma geografia aleatória, volúvel e fractal, em que edificado novo ou renovado coexiste lado a lado com manchas de arruinamento, num patchwork complexo. Essa configuraçáo pode ser entendida como mais uma expressáo da cidade fragmentada que Barata Salgueiro (1998) descreve como o novo padrão de organização urbana no capitalismo avançado, onde a lógica dominante é a do enclave e a da contiguidade sem continuidade, ou, usando o aparelho conceptual de Santos (1996, p. 284), a da predominância das "verticalidades" sobre as "horizontalidades".

$\mathrm{O}$ caso analisado deixou ainda evidenciado o papel do Estado e das políticas de regeneração na facilitação da rotação do capital no ambiente construído, beneficiando o reinvestimento no edificado e abreviando a presença de ruínas. Como vimos, as políticas públicas, sobretudo na última década, vieram criar condiçôes altamente vantajosas à reproduçáo do capital na regeneraçáo urbana. $\mathrm{O}$ racional alegado prendia-se com contrariar tendências de dispersão e promover o regresso à cidade compacta. Na prática, talvez porque "A cooperação entre Estado e mercado no capitalismo é a regra" e as políticas "são construídas e conduzidas no interesse 
e não contra o interesse dos mercados” (Bauman, 2010 [2009], p. 31), as medidas acabaram por favorecer a reocupação das áreas centrais mais nobres pelo capital.

Por último, uma referência à crise económica para salientar sobretudo questôes que o estudo do caso de Lisboa deixa em aberto. Os efeitos da recente crise financeira global gerada pelo colapso do mercado de hipotecas na produção de ruínas novas são um facto que tem sido documentado na bibliografia internacional (Pálsson, 2012; DeSilvey \& Edensor, 2013; Kitchin, O’Callaghan \& Gleeson, 2014). O estudo do caso de Lisboa não deixou evidente essa relação. É possível que isso se deva a limitaçóes da fonte de informação utilizada. $\mathrm{O}$ facto do recorte temporal deixar de fora o período pós-2011, precisamente os anos em que a recessão se agudizou com a crise da dívida soberana na zona euro, pode ser uma explicação. Outra razão prende-se com a insensibilidade das estatísticas. Edifícios que ficaram por concluir em consequência da falência dos promotores ou construtores são uma das estruturas ruiniformes mais comuns que a crise gerou (DeSilvey \& Edensor, 2013), mas essas construçóes abortadas escapam aos censos da habitação. Contudo, é também possível que a tendência de periferização do arruinamento detetada na Região de Lisboa nos anos mais recentes seja em parte reflexo da crise. É provável que as periferias, onde os estratos das classes médias-baixas predominam, tenham sido mais severamente afetadas pelo desinvestimento na habitaçáo social decorrente da política de austeridade e dos cortes nas despesas públicas, pelo incumprimento das dívidas bancárias contraídas na aquisição de casa própria, e pelas dificuldades na comparticipação de obras nos espaços comuns dos condomínios por parte de famílias que viram os seus rendimentos baixarem para níveis inferiores aos dos compromissos. A confirmar-se esta situação, estaremos em face de uma migração do capital dos segmentos mais baixos do imobiliário para os empreendimentos de topo de gama, onde se destaca a reabilitação de edifícios históricos em locais de prestígio, nomeadamente na cidade-centro. Uma investigação mais aturada sobre os efeitos da crise nas dinâmicas de arruinamento e nos processos de regeneração urbana será necessária para confirmar essa hipótese.

\section{Referências bibliográficas}

Abourahme, N. (2014). Ruinous city, ruinous time: Future suspended and the science fiction of the present. City, 18(4-5), 577-582. doi: 10.1080/13604813.2014.943925

André, I. \& Vale, M. (2012). Lisboa: tensiones entre ciudad y la metrópoli. In M. Balbo (Ed.), Europa: la ciudad central en el sistema urbano (pp. 209-239). Quito: Organización Latinoamericana y del Caribe de Centros Históricos (OLACCHI).

Barata Salgueiro, T. (1994). Novos produtos imobiliários e reestruturação urbana. Finisterra. Revista Portuguesa de Geografia, 29(57), 79-101. doi: http://dx.doi.org/10.18055/ Finis 1848

Barata Salgueiro, T. (1998). Cidade pós-moderna: espaço fragmentado. Território, 3(4), 39-53. http://www.revistaterritorio.com.br/pdf/04_4_salgueiro.pdf

Barata Salgueiro, T. (2001). Lisboa, periferia e centralidades. Oeiras: Celta. 
Baudrillard, J. (1970). La société de consommation. Ses mythes, ses structures. Paris: Ed. Denoel.

Bauman, Z. (2010 [2009]). Capitalismo parasitário e outros temas contemporâneos (E. Aguiar, Trad.). Rio de Janeiro: Zahar.

Beasley-Murray, J. (2010). Vilcashuamán. Telling stories in ruins. In J. Hell \& A. Schönle (Eds.), Ruins of Modernity (pp. 212-231). Durham e Londres: Duke University Press.

Berger, A. (2006). Drosscape: Wasting land in urban America. Princeton, NJ: Princeton Architectural Press.

Berman, M. (1982). All that is solid melts into air: The experience of modernity. Nova Iorque: Penguin Books.

Bontje, M. \& Musterd, S. (2012). Understanding shrinkage in European regions. Built Environment, 38(2), 153-161. doi: 10.2148/benv.38.2.153

Burguess, E. W. (1929). The growth of the city. An introduction to a research project. In R. E. Park, E. W. Burguess \& R. D. McKenzie (Eds.), The city (1984, 3a ed., pp. 47-62). Chicago, IL: The University of Chicago Press.

Bury, J. B. (1920). The idea of progress. An inquiry into its origin and growth. Londres: MacMillan $\&$ Co.

Buzar, S., Ogden, P., Hall, R., Haase, A., Kabisch, S. \& Steinfiihrer, A. (2007). Splintering urban populations: Emergent landscapes of reurbanisation in four European cities. Urban Studies, 44(4), 651-677. doi: 10.1080=00420980601185544

Carlos, A. F. A. (2007). O espaço urbano. Novos escritos sobre a cidade. São Paulo: Faculdade de Filosofia, Letras e Ciências Humanas da Universidade de São Paulo (FflCh/Usp).

Cheshire, P. (1995). A new phase of urban development in Western Europe? The evidence for the 1980s. Urban Studies, 32(7), 1045-1063. doi: 10.1080/00420989550012564

Couch, C. \& Cocks, M. (2013). Housing vacancy and the shrinking city: Trends and policies in the UK and the city of Liverpool. Housing Studies, 28(3), 499-519. doi: 10.1080/02673037.2013.760029

Couch, C., Sykes, O. \& Börstinghaus, W. (2011). Thirty years of urban regeneration in Britain, Germany and France: the importance of context and path dependency. Progress in Planning, 75(1), 1-52. doi: 10.1016/j.progress.2010.12.001

Dear, M. (2001). From Chicago to L.A. Making sense of urban theory. Thousand Oaks, Ca: Sage.

DeSilvey, C. \& Edensor, T. (2013). Reckoning with ruins. Progress in Human Geography, 37(4), 465-485. doi: 10.1177/0309132512462271

Dobraszczyk, P. (2015). Traversing the fantasies of urban destruction: Ruin gazing in Varosha. City, 19(1), 44-60. doi: 10.1080/13604813.2014.962877

Edensor, T. (2005). Industrial ruins: Spaces, aesthetics and materiality. Nova Iorque: Berg.

Ferreira, D. (2015). Os centros comerciais mortos na Área Metropolitana Norte de Lisboa. Dissertação de Mestrado em Gestão do Território e Urbanismo, Instituto de Geografia e Ordenamento do Território, Universidade de Lisboa, Lisboa.

Frey, W. H. (2005). Metro America in the new century: Metropolitan and central city demographic shift since 2000. Washington, DC: The Brookings Institution.

Gandy, M. (2013). Marginalia: Aesthetics, ecology, and urban wastelands. Annals of the Association of American Geographers, 103(6), 1301-1316. doi: 10.1080/00045608.2013.832105

Gaspar, J., Brito Henriques, E. \& Vale, M. (1998). Economic restructuring, social recomposition and recent urban changes in Portugal. GeoJournal, 46, 63-76. doi: 10.1023/A:1006987705815 
González-Ruibal, A. (2008). Time to destroy: An archaeology of supermodernity. Current Anthropology, 49(2), 247-279. doi: 10.1086/526099

Großmann, K., Beauregard, R., Dewar, M. \& Haase, A. (2012). European and us perspectives on shrinking cities. Urban Research \& Practice, 5(3), 360-363. doi: 10.1080/17535069.2012.727565

Hall, P. (1998). Cities in civilization: Culture, technology, and urban order. Nova Iorque: Pantheon Books.

Harvey, D. (1985). The urbanization of capital. Oxford: Basil Blackwell.

Harvey, D. (2012 [2010]). El enigma del capital y las crisis del capitalismo (J. Madariaga, Trad.). Madrid: Akal.

Hell, J. \& Schönle, A. (2010). Introduction. In J. Hell \& A. Schönle (Eds.), Ruins of Modernity (pp. 1-14). Durham e Londres: Duke University Press.

Horkheimer, M. \& Adorno, T. W. (2002 [1944]). Dialectic of Enlightenment. Philosophical fragments (E. Jephcott, Trad.). Stanford, CA: Stanford University Press.

Hospers, G.-J. (2014). Policy responses to urban shrinkage: From growth thinking to civic engagement. European Planning Studies, 22(7), 1507-1523. doi: 10.1080/09654313.2013.793655

Hoyt, H. (1939). The structure and growth of residencial neighborhoods in American cities. Washington, DC: Federal Housing Administration.

Kabisch, N. \& Haase, D. (2011). Diversifying European agglomerations: Evidence of urban population trends for the 21st century. Population, Space and Place, 17(3), 236-253. doi: $10.1002 /$ psp.600

Kitchin, R., O'Callaghan, C. \& Gleeson, J. (2014). The new ruins of Ireland? Unfinished estates in the post-Celtic Tiger era. International Journal of Urban and Regional Research, 38(3), 1069-1080. doi: 10.1111/1468-2427.12118

Martin, D. (2014a). Introduction: towards a political understanding of new ruins. International Journal of Urban and Regional Research, 38(3), 1037-1046. doi: 10.1111/14682427.12116

Martin, D. (2014b). Translating space: The politics of ruins, the remote and peripheral places. International Journal of Urban and Regional Research, 38(3), 1102-1119. doi: 10.1111/1468-2427.12121

Mateus, A. (Coord.). (2013). 25 anos de Portugal europeu: A economia, a sociedade e os fundos estruturais. Lisboa: Fundação Francisco Manuel dos Santos. https://www.ffms.pt/ upload/docs/23b69163-ee6d-4327-a324-03a0dfc0cfc5.pdf

Mendes, L. (2008). A nobilitação urbana no Bairro Alto: análise de um processo de recomposição sócio-espacial. Finisterra. Revista Portuguesa de Geografia, 41(81), 57-82. doi: http:// dx.doi.org/10.18055/Finis 1462

Millington, N. (2013). Post-industrial imaginaries: nature, representation and ruin in Detroit, Michigan. International Journal of Urban and Regional Research, 37(1), 279-296. doi: 10.1111/j.1468-2427.2012.01206.x

Mullins, P. (2012/08/19). The politics and archaeology of "ruin porn". [Blog post]. Retrieved from https://paulmullins.wordpress.com/2012/08/19/the-politics-and-archaeologyof-ruin-porn/

Pallagst, K., Schwarz, T., Popper, F. J. \& Hollander, J. B., (2009). Planning shrinking cities. Progress in Planning, 72(4), 223-232. 
Pálsson, G. (2012). These are not old ruins: A heritage of the Hrun. International Journal of Historical Archaeology, 16(3), 559-576. doi: 10.1007/s10761-012-0189-7

Peck, J., Theodor, N. \& Brenner, N. (2009). Neoliberal urbanism: models, moments, mutations. SAIS Review of International Affairs, 29(1), 49-66. doi: 10.1353/sais.0.0028

Rae, A. (2013). English urban policy and the return to the city: a decade of growth, 2001-2011. Cities, 32(June), 94-101. doi: 10.1016/j.cities.2013.03.012

Reis, S. (2007). 74-86 Arquitetura em Portugal: Uma leitura a partir da imprensa. Dissertação de Mestrado em Arquitetura, Território e Memória, Faculdade de Arquitetura, Universidade de Coimbra, Coimbra.

Ren, X. (2014). The political economy of urban ruins: redeveloping Shangai. International Journal of Urban and Regional Research, 38(3), 1081-1091. doi: 10.1111/14682427.12119

Rosa, H. (2013 [2005]). Social acceleration: A new theory of modernity (J. Trejo-Mathys, Trad.). Nova Iorque: Columbia University Press.

Santos, M. (1996). A natureza do espaço: Técnica e tempo, razão e emoção (2008, $4^{\mathrm{a}}$ ed.). São Paulo: Edusp.

Segado-Vázquez, F. \& Espinosa-Muñoz, V. M. (2015). La ciudad herida. Siete ejemplos paradigmáticos de rehabilitación urbana. EURE, 41(123), 103-129. doi: 10.4067/ S0250-71612015000300005

Simões, B. (2011, Março 22). Lisboa tem mais de 11 mil edifícios em ruínas ou devolutos. Negócios Online. Retrieved from http://www.jornaldenegocios.pt/economia/detalhe/ lisboa_tem_mais_de_11_mil_edifiacutecios_em_ruiacutenas_ou_devolutos.html

Soja, E. (2000). Postmetropolis: Critical studies of cities and regions. Oxford: Basil Blackwell.

Solà-Morales, I. (1995). Terrain vague. In C. C. Davidson (Ed.), Anyplace (pp. 188-123). Cambridge, MA: мIт Press.

Spengler, O. (1926 [1923]). The decline of the West (C. F. Atkinson, Trad.). Nova Iorque: Alfred A. Knopf.

Tallon, A. (2010). Urban regeneration in the uk. Oxon e Nova Iorque: Routledge.

Turok, I. \& Mykhnenko, V. (2007). The trajectories of European cities, 1960-2005. Cities, 24(3), 165-182. doi: 10.1016/j.cities.2007.01.007

Van den Berg, L., Drewett, R., Klaasen, L. H., Rossi, A. \& Vijverberg, C. H. T. (1982). Urban Europe. A study of growth and decline (Vol. 1). Oxford: Pergamon Press.

Virilio, P. (1977). Vitesse et politique: Essai de dromologie. París: Ed. Galilée.

Virilio, P. (1993). L’art du moteur. París: Galilée. 